UDC 579.222.4

HOVORUKHA V.M. ${ }^{凶}$, TASHYREV O.B.

Zabolotny Institute of Microbiology and Virology of the NAS of Ukraine, Ukraine, 03143, Kyiv, Zabolotny str., 154,e-mail:vira-govorukha@ukr.net

凶vira-govorukha@ukr.net

\title{
THERMODYNAMIC PROGNOSIS OF THE EFFICIENCY OF TOXIC METALS EXTRACTION FROM SOLUTION BY MICROORGANISMS AND THEIR GENETIC POTENTIAL
}

Aim. Thermodynamic justification of pathways of microbial interaction with metals and development of theoretical foundations of novel biotechnologies for purification of industrial waste water from environmentally hazardous metals-oxidizers $\left(\mathrm{CrO}_{4}{ }^{2-}\right.$, $\left.\mathrm{MoO}_{4}{ }^{2-}, \mathrm{WO}_{4}{ }^{2-}\right)$. Methods. The fields of stability of metal compounds in aqueous solutions in the coordinates of $\mathrm{pH}-\mathrm{Eh}$ were calculated using classic Pourbaix diagrams. The effectiveness of metals extraction from solutions was evaluated according to Gibbs free energy. Results. On the base of thermodynamic calculations conditions and efficiency of metals extraction by microorganisms was shown. Microbial reduction of $\mathrm{CrO}_{4}{ }^{2-}$ to insoluble $\mathrm{Cr}$ (III) hydroxide was the most effective. Additional carbon and energy sources are required for effective molybdate reduction. Extraction of tungstate can not be carried out by microorganisms. Conclusions. Thermodynamic prognosis is effective method for developing novel environmental biotechnologies for purification of environmentally hazardous metal-containing wastewater and simultaneous treatment of organic waste.

Keywords: thermodynamic prognosis, microbial interaction of with metals, metals extraction,

purification of metal-containing wastewater, environmental biotechnologies.

Deterioration of environment leads to an ecological catastrophe. Contamination of environment with compounds of toxic metals is one of the leading factors that negatively affects ecological situation $[1,2]$. Enterprises of heavy and chemical industry, galvanic sewage water, etc are the sources of such pollution. The wastewater discharged from such enterprises contains compounds of toxic metals, the concentration of which significantly exceeds the permissible standards. Ingress of such water to natural ecosystems leads to contamination with toxic metals and gradual destruction [3-5].

Application of microorganisms for purification of metal-containing wastewater is one of the most promising areas of research now. Isolation of specific metal-resistant strains is carried out. Also genetic modification of them is conducted to improve the efficiency of purification. As alternative direction microbial enzymes such as chromium reductases are purified to increase the efficiency of metal detoxification. However, such technologies require long-term studies and high costs to maintain the strains. It significantly reduces the profitability of technology. Although technologies for metalcontaining wastewater purification are now widely applied, the level of environmental pollution is increasing constantly $[3,4]$.

In this regard, there is a need to develop new approaches to solve the problem of wastewater treatment. To do this we have developed a concept of thermodynamic prognosis of nonspecific microbial interaction with metal compounds. It allows to prognose all possible pathways of microbial interaction with metal compounds, as well as to identify the most promising reactions that can be used for purification of metal-containing wastewater [6].

Therefore, the aim of our work was thermodynamic justification of pathways of microbial interaction with metals and development of theoretical foundations of novel biotechnologies for purification of industrial waste water from environmentally hazardous metals-oxidizers $\left(\mathrm{CrO}_{4}{ }^{2-}, \mathrm{MoO}_{4}{ }^{2-}\right.$, $\left.\mathrm{WO}_{4}{ }^{2-}\right)$.

\section{Materials and methods}

Thermodynamic prognosis of microbial interaction with metals is based on the calculation of the fields of metal compounds stability in aqueous solutions. To determine the stability fields of toxic metals compounds $\left(\mathrm{CrO}_{4}{ }^{2-}, \mathrm{MoO}_{4}{ }^{2-}, \mathrm{WO}_{4}{ }^{2-}\right)$, the classic Pourbaix diagrams were used in the coordinates of pH-Eh [7]. Possible pathways of microbial interaction with metal compounds were theoretically determined. The reactions that ensure transformation of soluble metal compounds into the insoluble were chosen. Such reactions served as the basis for substantiation of effective biotechnologies

\section{${ }^{\circ}$ HOVORUKHA V.M., TASHYREV O.B.}


for microbial extraction of toxic metals from solution.

The values of the standard potentials of metal anions reduction were calculated using the equations shown in the diagrams of metals stability in aqueous solution in coordinates $\mathrm{pH}-\mathrm{Eh}$ [7].

Interaction of microorganisms with metals was considered as a binary donor-acceptor reaction. Redox-reactions of hydrogen fermentation of organic compounds were donor system. Reactions of reduction of metal anions were acceptor system.

The evaluation of energy efficiency of $\mathrm{CrO}_{4}{ }^{2-}$ , $\mathrm{MoO}_{4}{ }^{2-}, \mathrm{WO}_{4}{ }^{2-}$ reduction and the possibility of their use by microorganisms was carried out using the Gibbs free energy equation:

$$
\begin{gathered}
\Delta \boldsymbol{G}_{o}=-\boldsymbol{n} \cdot \boldsymbol{F} \cdot \Delta \boldsymbol{E}_{o}=-\boldsymbol{n} \cdot \mathbf{9 6 , 5} \cdot \Delta\left(\boldsymbol{E}_{o} \text { Acceptor }-\boldsymbol{E}_{o}\right. \\
\text { Donor }) \mathrm{kJ} / \mathrm{M},[8]
\end{gathered}
$$

where $\Delta \boldsymbol{G}_{\boldsymbol{o}}$ - the free energy output in the binary donor-acceptor reaction $(\boldsymbol{k J} / \boldsymbol{M}), \boldsymbol{n}$ - the number of electrons in the redox-reaction, $\boldsymbol{F}$ - the Faraday constant $(23,07), \Delta \boldsymbol{E}_{\boldsymbol{o}}$ - the potential difference between acceptor (metals) and donor (dehydrogenase) reactions $(\boldsymbol{V})$.

For calculations, we used the values of standard potentials of reactions $\left(\boldsymbol{E}_{\boldsymbol{o}}{ }^{\prime}\right)$ commonly used in biology: at $\mathrm{pH}=7.0$ and $1 \mathrm{M}$ concentrations of oxidized and reduced forms of redox-components [9].

\section{Results and discussion}

Thermodynamic calculations carried out by us allow to determine theoretically acceptable pathways of metals transformation by microorganisms and to evaluate the most effective ones for metals extraction from solutions.

Thermodynamic calculations are the theoretical basis for the ways of detoxification of metal compounds by microorganisms.

Conditions that determine the possibility of microbial interaction with metals we proved previously [6]. Here are the most important points: 1 .
Dissimilative metabolism of microorganisms can be carried out only within the limits of water thermodynamic stability (WTS). The field of its stability is determined by the range of standard redoxpotentials $\left(\mathrm{E}_{\mathrm{o} \mathrm{pH}=7}\right)$ from $+814 \mathrm{mV}$ to $-414 \mathrm{mV} .2$. Microbial reduction of metals is possible only if the redox-potential of the reaction is within the limits of WTS. 3. Microbial reduction of metals is possible only if potential difference between acceptor and donor systems is not less than $100 \mathrm{mV}$. 4. The efficiency and rate of metal reduction by microorganisms is determined by free energy output $\left(\Delta \boldsymbol{G}_{\boldsymbol{o}}\right)$ that is proportional to the potential difference between acceptor and donor systems. 5. Microbial reduction of metals is nonspecific process, that is, it must be carried out by non-adapted to toxic metals microorganisms.

Fig. 1 shows graphical description of values of redox-potentials of reactions of chromium(VI), molybdenum(VI) and tungsten(VI) reduction in the coordinates of $\mathrm{pH}$-Eh. Given that the stability of each metal compound depends on the $\mathrm{pH}$, the length of the redox potential line is limited on both sides. The values of $\mathrm{pH}$ of soluble metal compounds transformation into insoluble are given in the Pourbaix equations, so we do not quote them here [7].

Redox-potentials of reduction of chromium(VI) and chromium(III) compounds are calculated according to the following equations of equilibrium states of metal compounds [7]:

The illustrations presented on Fig. 1 show that compounds of chromium(VI) can only be reduced to chromium (III) (reaction 1, 2), because the potentials of their reduction are in the limits of WTS. However, further reduction of chromium(III) is impossible, since the potential of the reaction of chromium(III) hydroxide reduction is outside WTS field (reaction 3).

$$
\begin{aligned}
& \left.\mathrm{Cr}_{2} \mathrm{O}_{7}^{2-}+14 \mathrm{H}^{+}+6 \mathrm{e}=2 \mathrm{Cr}^{3+}+7 \mathrm{H}_{2} \mathrm{O} \text { (reaction } 1\right) \\
& \mathrm{Eh}=1,333-0,1379 \mathrm{pH}+0,0098 \lg \frac{\left\{\mathrm{Cr}_{2} \mathrm{O}_{7}{ }^{2-}\right\}}{\left\{\mathrm{Cr}^{3+}\right\}^{2}} ; \mathbf{E}_{\mathbf{0}(\mathbf{p H}=\mathbf{5})}=\mathbf{+} \mathbf{6 4 4} \mathbf{~ m V} \\
& \mathrm{CrO}_{4}{ }^{2-}+(\mathrm{n}-1) \mathrm{H}_{2} \mathrm{O}+5 \mathrm{H}^{+}+3 \mathrm{e}=\mathrm{Cr}(\mathrm{OH})_{3} \cdot \mathrm{nH}_{2} \mathrm{O} \text { (reaction 2) } \\
& \mathrm{Eh}=1,244-0,0985 \mathrm{pH}+0,0197 \lg \left\{\mathrm{CrO}_{4}{ }^{2-}\right\} ; \mathbf{E}_{\mathbf{0}(\mathbf{p H}=7)}=\mathbf{+ 5 5 5} \mathbf{~ m V} \\
& \left.\mathrm{Cr}(\mathrm{OH})_{3}+3 \mathrm{H}^{+}+3 \mathrm{e}=\mathrm{Cr}^{0}+3 \mathrm{H}_{2} \mathrm{O} \text { (reaction } 3\right) \\
& \mathrm{Eh}=-0,654-0,0591 \mathrm{pH} ; \mathbf{E}_{\mathbf{o}(\mathbf{p H}=7)}=-\mathbf{1 0 6 8} \mathbf{~ m V}
\end{aligned}
$$




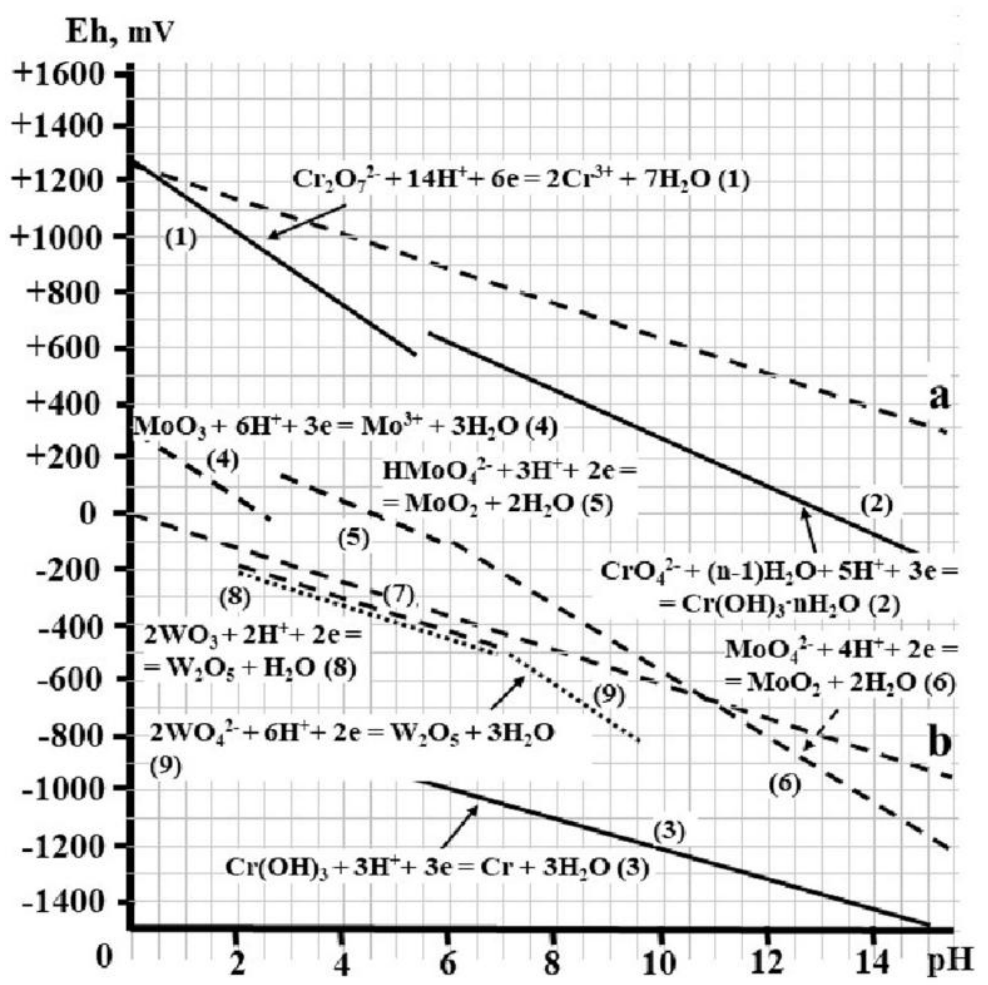

Fig. 1. Redox-states of metals: a (top) and $b$ (lower) - limit of thermodynamic stability of water: $a$ - is described by the equation: $\mathrm{O}_{2}+4 \mathrm{H}^{+}=2 \mathrm{H}_{2} \mathrm{O}$ and $\mathrm{Eh}=1,228-0,0591 \mathrm{pH}-0,0295 \cdot \mathrm{lgPH}_{2} ; \mathrm{b}-$ is described by the equation: $2 \mathrm{H}^{+}+$ $2 \mathrm{e}=\mathrm{H}_{2}$ and $\mathrm{Eh}=0,000-0,0591 \cdot \mathrm{pH}-0,0591 \cdot \operatorname{lgPH}_{2}$.

Redox-potentials of molybdenum(VI) compounds reduction are described by the following equations:

$$
\left.\mathrm{MoO}_{3}+6 \mathrm{H}^{+}+3 \mathrm{e}=\mathrm{Mo}^{3+}+3 \mathrm{H}_{2} \mathrm{O} \text { (reaction } 4\right)
$$

$$
\begin{gathered}
\mathrm{Eh}=0,317-0,1182 \mathrm{pH}-0,0591 \lg \left\{\mathrm{Mo}^{3+}\right\} ; \mathbf{E}_{\mathbf{0}(\mathbf{p H}=\mathbf{2})=+81 \mathbf{~ m V}} \\
\mathrm{HMoO}_{4}{ }^{2-}+3 \mathrm{H}^{+}+2 \mathrm{e}==\mathrm{MoO}_{2}+2 \mathrm{H}_{2} \mathrm{O}(\text { reaction } 5) \\
\mathrm{Eh}=0,429-0,0886 \mathrm{pH}+0,0295 \lg \left\{\mathrm{HMoO}_{4}^{-}\right\} ; \mathbf{E}_{\mathbf{0}(\mathbf{p H}=\mathbf{5})=-14 \mathbf{~ m V}} \\
\mathrm{MoO}_{4}{ }^{2-}+4 \mathrm{H}^{+}+2 \mathrm{e}=\mathrm{MoO}_{2}+2 \mathrm{H}_{2} \mathrm{O}(\text { reaction } 6) \\
\mathrm{Eh}=0,606-0,1182 \mathrm{pH}+0,0295 \lg \left\{\mathrm{MoO}_{4}{ }^{2-}\right\} ; \mathbf{E}_{\mathbf{0}(\mathbf{p H}=7)}=-\mathbf{2 2 1} \mathbf{~ m V}
\end{gathered}
$$

$$
\begin{gathered}
\mathrm{MoO}_{2}+4 \mathrm{H}^{+}+4 \mathrm{e}=\mathrm{Mo}^{\circ}+2 \mathrm{H}_{2} \mathrm{O}(\text { reaction } 7) \\
\mathrm{Eh}=-0,072-0,0591 \mathrm{pH} ; \mathbf{E}_{\mathbf{0}(\mathbf{p H}=7)}=-\mathbf{4 8 6} \mathbf{~ m V}
\end{gathered}
$$

Redox-potentials of tungsten(VI) compounds reduction correspond to the equations:

$$
\begin{aligned}
& 2 \mathrm{WO}_{3}+2 \mathrm{H}^{+}+2 \mathrm{e}=\mathrm{W}_{2} \mathrm{O}_{5}+\mathrm{H}_{2} \mathrm{O} \text { (reaction 8) } \\
& \mathrm{Eh}=-0,029-0,0591 \mathrm{pH} ; \mathbf{E}_{\mathbf{0}(\mathbf{p H}=\mathbf{5})}=\mathbf{- 3 2 5} \mathbf{~ m V} \\
& 2 \mathrm{WO}_{4}{ }^{2-}+6 \mathrm{H}^{+}+2 \mathrm{e}=\mathrm{W}_{2} \mathrm{O}_{5}+3 \mathrm{H}_{2} \mathrm{O} \text { (reaction 9) } \\
& \mathrm{Eh}=0,801-0,1773 \mathrm{pH}+0,0591 \lg \left\{\mathrm{WO}_{4}{ }^{2-}\right\} ; \mathbf{E}_{\mathbf{0}(\mathbf{p H}=7)}=\mathbf{- 4 4 0} \mathbf{~ m V} \text {. }
\end{aligned}
$$

Similar results are obtained for the reactions of molybdenum(VI) compounds reduction. It is theoretically possible to reduce molybdenum(VI) compounds to molybdenum(IV) and molybdenum(III), because the potentials of these reactions are within the limits of WTS (reactions $4,5,6$ ). However, the potential of reaction 7 is beyond the
WTS field. Therefore the reduction of molybdenum(IV) by microorganisms is impossible.

In contrast to the possibility of microbial reduction of chromium(VI) and molybdenum(VI) compounds, reduction of tungsten(VI) compounds by microorganisms is thermodynamically prohibited. For reactions 8 and 9 , reduction potentials of 
tungsten(VI) are outside the limits of WTS.

The main task of thermodynamic prognosis of microbial interaction with metals is the choice of optimal reaction of metal reduction by microorganisms, that ensures its rapid and effective removal from industrial wastewater. That is why reactions among those shown in Fig. 1 should be chosen to serve the basis for development of environmental biotechnologies.

Comparing reactions of chromium(VI) compounds reduction, it is clear that only reaction 2 leads to complete removal of this toxic metal from solution. Microorganisms can carry out this reaction in a wide range of $\mathrm{pH}$ (from 5.5 to 14.0). The reduced compound $\mathrm{Cr}(\mathrm{OH})_{3} \cdot \mathrm{nH}_{2} \mathrm{O}$ has a product of solubility $6.3 \cdot 10^{-31}$, that indicates complete removal of chromium from solution [10]. Obviously, reaction 1 can not be used for sewage purification, because chromium(VI) in the form of bichromate is reduced to a soluble cation $\mathrm{Cr}^{3+}$ at $\mathrm{pH}<5.5$.

Investigating microbial interaction with molybdenum(VI) compounds it is clear that reactions 5 and 6 are suitable for the effective removal of this metal from solution. The anions $\mathrm{HMoO}_{4}{ }^{2-}$ and $\mathrm{MoO}_{4}{ }^{2-}$ are reduced to completely insoluble $\mathrm{MoO}_{2}$ in the wide range of $\mathrm{pH}$ (from 2.7 to 14.0). Microbial reduction of molybdenum(VI) in strongly acidic conditions can not be applied in purifying biotechnologies, as it leads to the formation of soluble cation $\mathrm{Mo}^{3+}$.

There is a thermodynamic prohibition on microbial reduction of both soluble and insoluble compounds of tungsten(VI). Thus, for reduction

1.

$$
\begin{aligned}
& 3 \mathrm{e} 1,5 \mathrm{H}_{2}=3 \mathrm{H}^{+}+3 \mathrm{e} \\
& \mathrm{CrO}_{4}{ }^{2-}+(\mathrm{n}-1) \mathrm{H}_{2} \mathrm{O}+5 \mathrm{H}^{+}+3 \mathrm{e}= \\
& \mathrm{Cr}(\mathrm{OH})_{3} \cdot \mathrm{nH}_{2} \mathrm{O}
\end{aligned}
$$

2.



3. $2 \mathrm{e}$

$$
\begin{aligned}
& \mathrm{H}_{2}=2 \mathrm{H}^{+}+2 \mathrm{e} \\
& 2 \mathrm{WO}_{4}{ }^{2-}+6 \mathrm{H}^{+}+2 \mathrm{e}=\mathrm{W}_{2} \mathrm{O}_{5}+3 \mathrm{H}_{2} \mathrm{O}
\end{aligned}
$$

reactions of $\mathrm{WO}_{3}$ and $\mathrm{WO}_{4}{ }^{2-}$ to $\mathrm{W}_{2} \mathrm{O}_{5}$, the value of redox-potentials in a wide range of $\mathrm{pH}$ (from 2.0 to 9.0 ) is out of the limits of WTS. It follows that microbial reduction of tungsten(VI) compounds can not be used to extract them from aqueous solutions, in particular sewage.

The efficiency of metal reduction is proportional to the potential difference between the two systems: donor (redox-enzymes of microorganisms) and acceptor (metals). Hence, it is clear that lowpotential redox-enzymes, in particular dehydrogenase, are the most effective reducers of metalsoxidizers. For example, when cytochrome with the redox potential of $+300 \mathrm{mV}$ [8] is donor system potential difference between the cytochrome system and chromate $(+555 \mathrm{mV})$ is only $255 \mathrm{mV}$. If dehydrogenase $(-414 \mathrm{mV})$ [8] is donor system potential difference will be $969 \mathrm{mV}$ in relation to chromate. It is 3.8 times higher than that of cytochromes. That is why, we considered dehydrogenase $(-414 \mathrm{mV})$ to be donor system prognosing microbial interaction with metals and developing the theoretical foundations for effective biotechnologies for extraction of metals from wastewater. Thus, the next step was to evaluate the effectiveness of such binary redoxreactions.

According to potential difference of three donor-acceptor reactions, it is clear that microbial reduction of chromates will be the most effective process. Reduction of molybdate will take place with lower efficiency. Tungsten compounds will not be reduced.

$$
\begin{aligned}
& \boldsymbol{E}_{\boldsymbol{o}}{ }^{\prime}=-414 \mathrm{mV} \quad \Delta \boldsymbol{E}_{\boldsymbol{o}}{ }^{\prime}=969 \mathrm{mV} \\
& \boldsymbol{E}_{\boldsymbol{o}}{ }^{\prime}=+555 \mathrm{mV}
\end{aligned}
$$

$\boldsymbol{E}_{\boldsymbol{o}}{ }^{\prime}=-414 \mathrm{mV}$

$\boldsymbol{E}_{\boldsymbol{o}}{ }^{\prime}=-221 \mathrm{mV}$

$\Delta \boldsymbol{E}_{\boldsymbol{o}}{ }^{\prime}=193 \mathrm{mV}$

$\boldsymbol{E}_{\boldsymbol{o}}{ }^{\prime}=-414 \mathrm{mV}$

$\Delta \boldsymbol{E}_{\boldsymbol{o}}{ }^{\prime}=-26 \mathrm{mV}$

$\boldsymbol{E}_{\boldsymbol{o}}{ }^{\prime}=-440 \mathrm{mV}$

For the reaction of chromate reduction:

$$
\Delta \boldsymbol{G}_{o}=-\boldsymbol{n} \cdot \boldsymbol{F} \cdot \Delta \boldsymbol{E}_{o}=-3 \cdot 96,5 \cdot \Delta(+0,555-(-0,414))=-280,77 \mathrm{~kJ} / \mathrm{M} .
$$

Reducing of molybdate:

$$
\Delta \boldsymbol{G}_{o}=-n \cdot \boldsymbol{F} \cdot \Delta \boldsymbol{E}_{o}=-2 \cdot 96,5 \cdot \Delta(-0,221-(-0,414))=-37,26 \mathrm{~kJ} / \mathrm{M} \text {. }
$$

For the binary redox-system "dehydrogenase- $\mathrm{WO}_{4}{ }^{2-"}$ the free energy output acquires positive values:

$$
\Delta \boldsymbol{G}_{o}=-\boldsymbol{n} \cdot \boldsymbol{F} \cdot \Delta \boldsymbol{E}_{o}=-2 \cdot 96,5 \cdot \Delta(-0,440-(-0,414))=5,02 \mathrm{~kJ} / \mathrm{M} \text {. }
$$


The free energy output $\Delta \boldsymbol{G}_{\boldsymbol{o}}$ is an integral indicator of the efficiency of metal reduction in binary-redox reactions.

Estimation of values of free energy output allows to determine the order of metal extraction in case of simultaneous presence of several metals in solution. For example, if $\mathrm{CrO}_{4}{ }^{2-}$ and $\mathrm{MoO}_{4}{ }^{2-}$ are present in sewage at the same time, microorganisms will reduce chromate firstly. It is due to the fact that reduction potential of chromate is at $776 \mathrm{mV}$ greater than the one of molybdate. In addition, it is obvious that reduction of low-potential molybdate will require much more time than high-potential chromate. It is important for practical application in industrial biotechnologies, because presence of molybdate requires significant increase in retention time of the wastewater in the treatment plant. Also it is necessary to provide additional sources of carbon and energy required by microorganisms for the two-phase reduction of metals. Indeed, firstly these sources will be spent by microorganisms for rapid reduction of chromate. Under these conditions, lack of electron donors may occur to reduce molybdate in the second phase. Therefore, additional sources of electrons will be required after chromate reduction process is completed.

Such regularities allow to determine the strategic aspects of development of effective purification biotechnologies. When soluble compounds (for example, melasse) are used in the plant as the source of carbon and energy the time of its loading should be determined for effective reduction of molybdate in the second phase of purification. However, alternative variant to provide microorganisms with sources of carbon and energy is possible. For example, application of natural insoluble polymeric compounds that are easily assimilated by anaerobic microorganisms (potato peelings of food industries, etc.) is promising alternative direction. High concentration of such compounds will provide microorganisms with necessary energy, and their insoluble form will not lead to suppression of microbial growth under the mechanism of concentration inhibition.

Thermodynamic prognosis of microbial reduction of metals allows not only to achieve maximum effect of metal-containing wastewater purification, but also to avoid extremely undesirable consequences. For example, insoluble hydroxide $\mathrm{Cr}(\mathrm{OH})_{3} \cdot \mathrm{nH}_{2} \mathrm{O}$ is formed during microbial reduction of chromate at $\mathrm{pH} \geq 5.5$ (Fig. 1, reaction 2). However, chromate is reduced to soluble cation $\mathrm{Cr}^{3+}$ at lower $\mathrm{pH}$ values (Fig. 1, reaction 1). Conse- quently, in case of medium acidification the ultimate goal of microbial interaction with metals, removal of toxic chromium from solution is not achieved. Strong acidification of medium always occurs during hydrogen fermentation of soluble carbohydrates and their insoluble polymeric compounds (starch, cellulose, etc.). In accordance with the reaction of hydrogen fermentation of carbohydrates $\mathrm{C}_{6} \mathrm{H}_{12} \mathrm{O}_{6}+2 \mathrm{H}_{2} \mathrm{O}=2 \mathrm{CH}_{3} \mathrm{COOH}+4 \mathrm{H}_{2}+$ $2 \mathrm{CO}_{2}$ [11] the $\mathrm{pH}$ of medium may decrease to 3.0...4.0 [12]. In this case, the equilibrium of the redox-reaction is obviously shifted toward the formation of soluble $\mathrm{Cr}^{3+}$. It should be noted that acidification of medium occurs in the first phase of fermentation (hydrolysis of polymers). Therefore, it is necessary to provide continuous control of $\mathrm{pH}$ and the possibility of its rapid correction in biotechnologies.

Based on the literature data, physicochemical methods of transformation of metal compounds are complex and costly [1-3]. Therefore, methods of metal extraction from solutions by microorganisms are becoming especially topical now. Application of microorganisms in treatment biotechnologies is now restricted due to low metabolic activity and viability. Increase the efficiency of the process using genetically modified microorganisms is limited by the lack of data on their behavior in the environment. Application of purified enzymes is perspective, but costly for large-scale implementation [3]. However, there is still need to investigate genetic potential of microorganisms, biochemical mechanisms and conditions of microbial reduction of metals [13].

It should be emphasized that theoretical thermodynamic calculations are essential for practical application. Thus, the rate and efficiency of microbial reduction of metals is determined only by the value of potential difference between donor and acceptor systems. It follows that microbial reduction of metals is a non-specific process, that is, it can be carried out by microorganisms that are not adapted to toxic metals in high concentrations.

Sources of such microorganisms are anaerobic microbial communities of natural ecosystems [5]. Its application avoids the problem of isolation of specific metal-resistant microorganisms or enzymes [3].

\section{Conclusions}

There are necessary and sufficient requirements for the development of biotechnology for the efficient removal of metals-oxidizers from industri- 
al wastewater. 1. Microorganisms of hydrogen fermentation should be used for the most rapid and effective extraction of chromate and molybdate from sewage. They provide the greatest difference of redox-potentials in the donor-acceptor system of "microorganisms-metal". 2. In order to ensure effective removal of chromate and molybdate, insoluble carbon and energy sources are required. Environmentally hazardous rotten vegetables and food waste can be used. Their application will ensure not only extraction of toxic metals, but will also lead to destruction of organic waste. 3. Optimal extraction of metals takes place in neutral and slightly alkaline conditions. Continuous control and correction of $\mathrm{pH}$ is required in biotechnologies. 4. Reductive microbial transformation of metals can not be used to extract tungstate.

Thus, thermodynamic prognosis is effective method for developing novel environmental biotechnologies for purification of environmentally hazardous metal-containing wastewater and simultaneous treatment of organic waste.

\section{References}

1. Lloyd J.R., Lovley D.R. Microbial detoxification of metals and radionuclides. Environmental biotechnology. 2001. Vol. 12 (3). P. 248-253. doi: 10.1016/S0958-1669(00)00207-X.

2. Zafar S., Aqil F., Ahmad I. Metal tolerance and biosorption potential of filamentous fungi isolated from metal contaminated agricultural soil. Bioresource Technology. 2007. Vol. 98 (13). P. 2557-2561. doi: 10.1016/j.biortech.2006.09.051.

3. Cheung K.H., Gu J.-D. Mechanism of hexavalent chromium detoxification by microorganisms and bioremediation application potential: A review. International Biodeterioration \& Biodegradation. 2007. Vol. 59 (1). P. 8-15. doi: 10.1016/j.ibiod.2006.05.002.

4. Congeevaram S., Dhanarani S., Park J., Dexilin M., Thamaraiselvi K. Biosorption of chromium and nickel by heavy metal resistant fungal and bacterial isolates. Journal of Hazardous Materials. 2007. Vol. 146 (1-2). P. 270-277. doi: 10.1016/j.jhazmat.2006.12.017.

5. Sturm G., Dolch K., Richter K., Rautenberg M., Gescher J. Metal Reducers and Reduction Targets. A Short Survey About the Distribution of Dissimilatory Metal Reducers and the Multitude of Terminal Electron Acceptors. Microbial Metal Respiration. 2013. P. 129-159. doi: 10.1007/978-3-642-32867-1_6.

6. Tashyrev O.B., Galinker E.V., Andreyuk E.I. Thermodynamic prognosis of redox-interaction of microorganisms with metalsoxidizers. Reports of the National Academy of Sciences of Ukraine. 2008. P. 166-172. (In Russian).

7. Pourbaix M. Atlas of electrochemical equilibria in aqueous solutions. Oxford: Pergamon Press, 1963. 320 p.

8. $\quad$ Shlegel G. General microbiology. M.: Mir, 1987. 567 p. (In Russian).

9. Lehninger A., Nelson D., Cox M. Principles of Biochemistry, 2nd ed. New York: Worth, 1993.

10. Lurie Y.Y. Handbook of Analytical Chemistry. M.: Himiya, 1979. 480 p. (In Russian).

11. Kondratieva E.N. Role of microorganisms in the cycle of gases in nature. M.: Nauka, 1979. 288 p. (In Russian).

12. Tashyreva A., Tashyrev O., Prytula I. The novel comprehensive approach for non-food agricultural and landfill biomass microbial fermentation and biogas production. Biotechnology and Plant Breeding Perspectives. 2014. P. 347-356.

13. Lloyd J.R. Microbial reduction of metals and radionuclides. FEMS Microbiology Reviews. 2003. Vol. 27. P. 411-425.

\section{ГОВОРУХА В.М., ТАШИРЕВ О.Б.}

Інститут мікробіології і вірусологї̈ ім. Д.К. Заболотного НАН України, Україна, 03143, м. Київ, вул. Академіка Заболотного, 154, e-mail: vira-govorukha@ukr.net

\section{ТЕРМОДИНАМІЧНЕ ПРОГНОЗУВАННЯ ЕФЕКТИВНОСТІ ВИЛУЧЕННЯ IЗ РОЗЧИНУ ТОКСИЧНИХ МЕТАЛІВ МІКРООРГАНІЗМАМИ ТА ЇХ ГЕНЕТИЧНИЙ ПОТЕНЦААЛ}

Mema. Термодинамічне обгрунтування шляхів взаємодії мікроорганізмів з металами та розробка теоретичних основ нових біотехнологій для очищення промислових стічних вод від екологічно небезпечних металівокиснювачів $\left(\mathrm{CrO}_{4}^{2-}, \mathrm{MoO}_{4}{ }_{4}^{2-}, \mathrm{WO}_{4}^{2-}\right)$. Методи. Поля стійкості сполук металів у водних розчинах у координатах $\mathrm{pH}-$ Ех були розраховані, використовуючи класичні діаграми Пурбе. Ефективність вилучення металів з розчинів оцінювалася відповідно до зміни вільної енергії Гіббса. Результати. На основі термодинамічних розрахунків показано умови та ефективність вилучення металів мікроорганізмами. Найбільш ефективним було відновлення мікроорганізмами $\mathrm{CrO}_{4}{ }_{4}^{2-}$ до нерозчинного гідроксиду $\mathrm{Cr}(\mathrm{III})$. Додаткові джерела вуглецю та енергії потрібні для ефективного відновлення молібдату. Вилучення вольфраму не може бути здійснено мікроорганізмами. Висновки. Термодинамічний прогноз $є$ ефективним методом для розробки нових природоохоронних біотехнологій для очищення екологічно небезпечних металовмісних стічних вод та одночасного знешкодження органічних відходів.

Ключові слова: термодинамічний прогноз, взаємодія мікроорганізмів з металами, екстракція металів, очищення металовмісних стічних вод, природоохоронні біотехнології. 